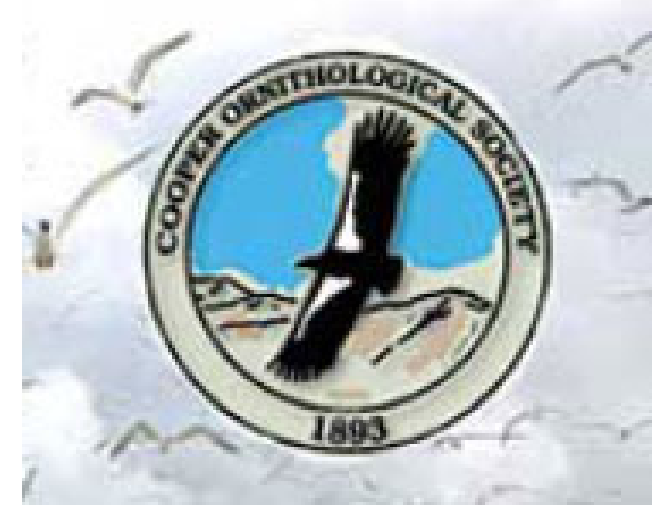

Survival Rates of Cassin's and Rhinoceros Auklets at Triangle Island, British Columbia Author(s): Douglas F. Bertram, Ian L. Jones, Evan G. Cooch, Hugh A. Knechtel, Fred Cooke Reviewed work(s):

Source: The Condor, Vol. 102, No. 1 (Feb., 2000), pp. 155-162

Published by: University of California Press on behalf of the Cooper Ornithological Society Stable URL: http://www.jstor.org/stable/1370 416

Accessed: 23/04/2012 16:03

Your use of the JSTOR archive indicates your acceptance of the Terms \& Conditions of Use, available at http://www.jstor.org/page/info/about/policies/terms.jsp

JSTOR is a not-for-profit service that helps scholars, researchers, and students discover, use, and build upon a wide range of content in a trusted digital archive. We use information technology and tools to increase productivity and facilitate new forms of scholarship. For more information about JSTOR, please contact support@jstor.org. 


\title{
SURVIVAL RATES OF CASSIN'S AND RHINOCEROS AUKLETS AT TRIANGLE ISLAND, BRITISH COLUMBIA ${ }^{1}$
}

\author{
DOUglas F. BERTRAM \\ Simon Fraser University, Department of Biological Sciences, 8888 University Drive, Burnaby, B.C., V5A 1S6, \\ Canada, and Canadian Wildlife Service, Pacific Wildlife Research Center, RR1 5421 Robertson Road, Delta, \\ B.C., V4K 3N2, Canada, e-mail: dbertram@sfu.ca \\ IAN L. JONES \\ Department of Biology, Memorial University of Newfoundland, St. John's, Newfoundland, A1B 3X9, Canada \\ Evan G. $\mathrm{CoOCH}^{2}$ and Hugh A. Knechtel \\ Simon Fraser University, Department of Biological Sciences, 8888 University Drive, Burnaby, B.C., \\ V5A IS6, Canada \\ Fred COOKE \\ Simon Fraser University, Department of Biological Sciences, 8888 University Drive, Burnaby, B.C., V5A 1S6, \\ Canada, and Canadian Wildlife Service, Pacific Wildlife Research Center, RRI 5421 Robertson Road, Delta, \\ B.C., V4K 3N2, Canada
}

\begin{abstract}
We estimated survival of Cassin's Auklet (Ptychoramphus aleuticus) and Rhinoceros Auklet (Cerorhinca monocerata) from recapture rates during 1994-1997. For both species, a two "age"-class model provided the best fit. Estimates of local adult survival were significantly lower for Cassin's Auklet $(0.672 \pm 0.047)$ than for Rhinoceros Auklet $(0.829 \pm 0.095)$. Our estimate of survival appears lower than that required for the maintenance of a stable population of Cassin's Auklets. The available information indicates that a low survival rate and a declining population at Triangle Island are plausible, particularly given the recent large scale oceanographic changes which have occurred in the North Pacific Ocean. Nevertheless, additional mark-recapture data and indexes of population size are required to rigorously demonstrate population declines at the world's largest Cassin's Auklet colony.

Key words: Alcidae, Cassin's Auklet, Cerorhinca monocerata, demography, Ptychoramphus aleuticus, Rhinoceros Auklet, seabird conservation and management.
\end{abstract}

\section{INTRODUCTION}

Estimates of adult annual survival for North $\mathrm{Pa}$ cific seabirds are rare but fundamental to demographic investigations needed for sound conservation and management decisions. We initiated a long-term mark and recapture study of Cassin's Auklets (Ptychoramphus aleuticus) and Rhinoceros Auklets (Cerorhinca monocerata) at Triangle Island, British Columbia in 1994. These two species are representative of some of the variation in auk ecology because of their different body size (ca. $190 \mathrm{~g}$ versus ca. $500 \mathrm{~g}$, respectively) and foraging ecology (planktivore versus piscivore). Triangle Island is the site of the largest and most diverse seabird colony in British Columbia and has large colonies of both

\footnotetext{
${ }^{1}$ Received 2 November 1998. Accepted 19 October 1999.

${ }^{2}$ Current address: Department of Natural Resources, Cornell University, Ithaca, New York 14853.
}

Cassin's Auklets and Rhinoceros Auklets. The breeding population of Cassin's Auklet at Triangle Island was estimated as 547,637 pairs in 1989 (Rodway 1991), comprising the largest known colony of this species. The breeding population of Rhinoceros Auklet was estimated as 41,682 pairs in 1989 (Rodway 1991), making Triangle Island the third largest colony of this species in British Columbia.

Our main objective here is to report the first estimates of local survival on Triangle Island. We also tested for differences between netting sites because the locations have different mixtures of the two species and hence varying potential for interspecific nest site competition (Vermeer et al. 1979, Wallace et al. 1992). The study was not confined to breeding birds but rather included all birds captured at our netting sites. Therefore, we also address the issue of estimating survival in the presence of transient birds. 


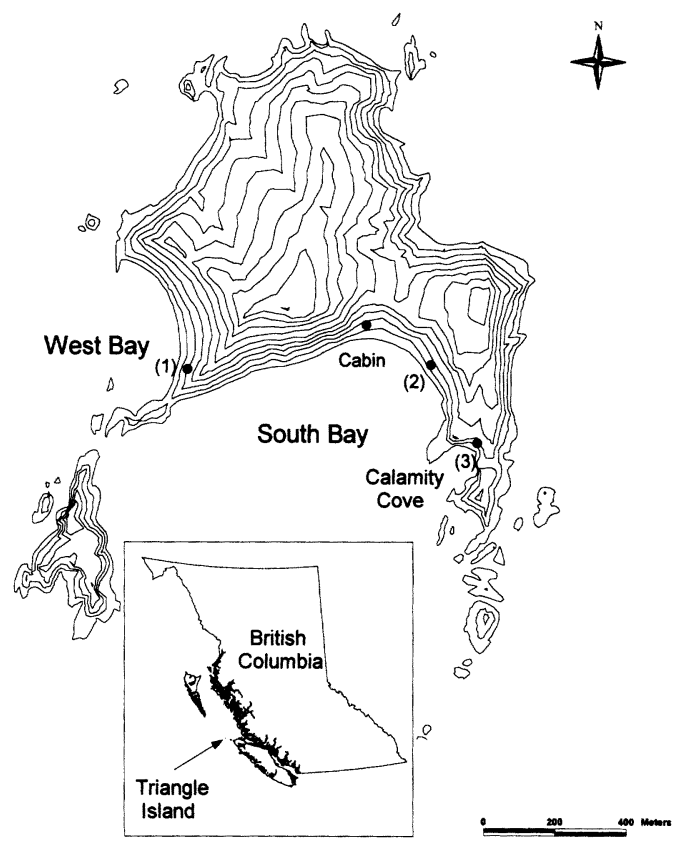

FIGURE 1. Locations of netting sites in West Bay (1), South Bay (2), and Calamity Cove (3), and the cabin at Triangle Island, British Columbia.

\section{METHODS}

\section{STUDY AREA}

We conducted fieldwork at three study plots on the south and southwest sides of Triangle Island, British Columbia, Canada $\left(50^{\circ} 52^{\prime} \mathrm{N}, 1^{\prime} 9^{\circ} 05^{\prime} \mathrm{W}\right.$; Fig. 1). The plot at West Bay (1) was located in an area densely occupied by Cassin's Auklets only, the South Bay plot (2) was located just below the center of Rhinoceros Auklet's main colony (high density Rhinoceros Auklets, low density Cassin's Auklets), and the Calamity Cove plot (3) was located in an area of moderate density of both auklet species (Fig. 1).

Cassin's and Rhinoceros Auklets were trapped using soft plastic "pheasant" nets erected vertically on guyed polyvinyl chloride plastic poles at the base of nesting slopes on the three plots. The net sizes were approximately $15 \mathrm{~m} \times 3 \mathrm{~m}$ in West Bay and $20 \mathrm{~m} \times 3 \mathrm{~m}$ in both South Bay and Calamity Cove. To minimize disturbance to the study populations, we trapped birds as they departed from the colony during the early morning hours (02:00 to 05:30) after most arrivals had ceased. The nets were usually taken down before first light because we were holding as many birds as could be processed before dawn.
For safety reasons, we did not band in rain. Under strong winds the nets would bend, so we did not trap under those conditions. For Cassin's Auklet only, we gauged the ages and breeding status of birds by scoring the iris color type as white, offwhite, light brown, or brown, based upon minor modifications of the technique of Manuwal (1978). Eye color of Cassin's Auklet becomes lighter as the birds age and mature (Emslie et al. 1990). In our study, eye colors other than white proved to be difficult to score reliably, and preliminary analyses suggested that eye color is an imprecise proxy for true age. Note that breeding propensity (and hence recapture rates) of young birds are likely to be lower than for older birds. We restricted our analyses to white eyed birds (65\% of our sample) because this treatment of the data had the least potential for results to be confounded by age effects.

\section{SURVIVAL ESTIMATION}

Local adult annual survival $(\phi)$ and recapture $(p)$ rates were estimated using methods described in Lebreton et al. (1992) and Burnham and Anderson (1998). We used program MARK (White and Burnham 1999) to model local survival and recapture rates.

Following Burnham and Anderson (1998), we first defined a candidate model set, which included a fully parameterized global model. Because our analyses were restricted to birds marked as adults, true age effects are unlikely. However, heterogeneity in capture can lead to apparent differences in survival estimated over the first interval after marking relative to survival estimated over subsequent intervals. To accommodate possible effects of heterogeneity in capture rates among marked individuals, the global model was structured to allow survival during the first year after marking (first "age") to differ from survival estimated over subsequent years $(2+$ "age"). Structurally, this is analogous to age-differences in survival ("age" models, sensu Lebreton et al. 1992). For our global survival model, we used a two "age"class model with site $\times$ time-dependence in the first year after marking, and constant site-specific survival after the second year following marking $\left\{\phi_{\mathrm{a} 2 \mathrm{~g}^{*} \mathrm{tg}}\right\}$. We did not incorporate timedependence into the second "age"-class in order to improve the precision of the estimate because the final estimates for both "age" classes are not separately identifiable. Because birds were banded 
as unknown aged adults, we did not incorporate age-structure into the recapture parameter in the global model, but allowed for site-specific differences $\left\{p_{g^{*}}\right\}$. The goodness-of-fit (GOF) of the global model to the data was determined using a parametric bootstrap approach (described below). The candidate model set included the global model and all possible reduced parameter models derived from the global model. The final candidate model set included a total of 24 models. Model notation followed Lebreton et al. (1992). The factorial structure of the model is represented by subscripting the primary parameters $\phi$ and $p$ using " $a$ " for putative "age" effects, $t$ for time effects, and $g$ for group sampling region or species differences. Relationships among factors were indicated using standard linear models notation.

Following Lebreton et al. (1992) and Burnham and Anderson (1998), model selection was based on comparison of the quasi Akaike Information Criterion $(\mathrm{QAIC})$ :

$$
\mathrm{QAIC}_{c}=\frac{-2 \ln (L)}{\hat{c}}+2 n p+\frac{2 n p(n p+1)}{n_{e s s}-n p-1}
$$

where $L$ is the model likelihood, $n p$ is the number of estimable parameters, $n_{\text {ess }}$ is the effective population size, and $\hat{c}$ is quasi-likelihood adjustment for overdispersion in the data. The model likelihoods, number of estimable parameters, and the effective population size are estimated directly by the program MARK. The quasi-likelihood parameter was estimated using the mean of simulated values of $\hat{c}$ from the bootstrap GOF testing 1,000 bootstrap samples (see above). Individual $\hat{c}$ values for each bootstrapped sample were derived by dividing the bootstrapped model GOF $\chi^{2}$ by the model degrees of freedom. $\hat{c}$ is asymptotically 1.0 if the model fits the data perfectly.

The model with the lowest $\mathrm{QAIC}_{c}$ is accepted as the most parsimonious model for the data. Comparisons among models in the candidate set were accomplished by deriving an index of relative plausibility, using normalized Akaike weights (Burnham and Anderson 1998). Individual model Akaike weights $w_{i}$ were calculated as:

$$
\mathrm{W}_{\mathrm{i}}=\frac{\left\{\exp \left(\frac{-\Delta \mathrm{QAIC}_{c}}{2}\right)\right\}}{\sum\left\{\exp \left(-\frac{\Delta \mathrm{QAIC}_{c}}{2}\right)\right\}}
$$

where $\triangle \mathrm{QAIC}_{c}$ is the absolute numerical difference in $\mathrm{QAIC}_{c}$ between a given model and the model in the candidate model set with the lowest QAIC $_{c}$. The ratio of $\mathrm{w}_{\mathrm{i}}$ between any two models indicates the relative degree to which a particular model is better supported by the data than the other model. To account for uncertainty in model selection (Burnham and Anderson 1998), we report parameter estimates $\hat{\theta}$ and associated standard errors derived by averaging over all models in the candidate model set, weighted by Akaike model weights sensu Buckland et al. (1997):

$$
\operatorname{avg}(\hat{\theta})=\sum_{i=1}^{R} \mathrm{w}_{\mathrm{i}} \hat{\theta}_{\mathrm{i}}
$$

where $\mathrm{w}_{\mathrm{i}}$ reflects the Akaike weight for model $i$.

\section{RESULTS}

\section{BANDING SUMMARY}

Netting effort for Rhinoceros Auklet varied between years (1994: $54 \mathrm{hr}$; 1995: $81 \mathrm{hr}$; 1996: 47 hr; 1997: $77 \mathrm{hr}$ ) and was lowest in 1996, particularly at Calamity Cove, due to constraints imposed by weather. In 1994, five Rhinoceros Auklets which had been banded previously on Triangle Island (three in 1984, one in 1986, one in 1989) were recaptured. In 1995 there was a recapture of a bird banded on Triangle Island in 1984 which makes it the oldest banded bird on record at $11+$ years. In our study, no Rhinoceros Auklets were recaptured at locations different from the site of original banding.

For Cassin's Auklet, netting effort also was lowest in 1996 (1994: $63 \mathrm{hr}$; 1995: $91 \mathrm{hr}$; 1996: $50 \mathrm{hr}$; 1997: $112 \mathrm{hr}$ ). Two birds were recaptured at locations different from the site of original banding. One bird, originally banded in 1994 at West Bay North on 18 June was recaptured again in 1994 at Calamity Cove on 25 June. The other, originally banded in 1997 in West Bay was recaptured incidentally at the cabin (Fig. 1) in 1997.

\section{SURVIVAL ANALYSIS}

Rhinoceros Auklet. Because $>99 \%$ of all the captures of Rhinoceros Auklets on Triangle Island occurred at Calamity Cove and South Bay, we restricted our analyses to these two sites. From 1994-1996, a total of 843 individual adults were marked and released at these two sites, of which 449 were recaptured at least once 
TABLE 1. Reduced $m$-array of Cassin's Auklet and Rhinoceros Auklet marked and recaptured from Triangle Island. Number pooled over all banding sites.

\begin{tabular}{llrrrrr}
\hline \multicolumn{1}{c}{ Species } & Year & $\mathrm{R}_{\mathrm{i}}$ & \multicolumn{1}{c}{1995} & 1996 & 1997 & $\mathrm{r}_{\mathrm{i}}$ \\
\hline Rhinoceros & 1994 & 478 & 156 & 44 & 39 & 239 \\
Auklet & 1995 & 410 & & 87 & 57 & 144 \\
& 1996 & 242 & & & 66 & 66 \\
& $\mathrm{~m}_{\mathrm{j}}$ & & 156 & 131 & 162 & \\
Cassin's Auklet & 1994 & 888 & 345 & 67 & 19 & 431 \\
& 1995 & 1,030 & & 240 & 61 & 301 \\
& 1996 & 600 & & & 140 & 140 \\
& $\mathrm{~m}_{\mathrm{j}}$ & & 345 & 307 & 220 & \\
\hline
\end{tabular}

$\mathbf{R}_{\mathrm{i}}=$ number of marked individuals released in year (i), including both newly marked and previously marked individuals. For example, in 1995 410 marked Rhinoceros Auklets were released. Of these, 254 were newly marked, 156 were previously marked birds $(254+156=410)$. Annual values are the number from a given release cohort first captured in that year (including newly and previously marked individuals). $r_{i}$ is the total number of individuals from a release cohort captured at least once. $m_{j}$ is the total number of recaptures in a given year.

(Table 1). The data satisfactorily fit the two "age"-class global model $\left\{\phi_{\mathrm{a} 2} \mathrm{~g}^{*} \mathrm{Jg} p_{\mathrm{g}^{*} \mathrm{t}}\right\}(P>$ 0.5 ), with no indication of significant extra-binomial variation in the data $(\hat{c}=1.039 \pm 0.039$; mean $\pm S E$ ).

The most parsimonious model in the candidate model set was a model where the survival rates varied with time from 1994-1996 during the interval between the year of marking and the next year (the first "age"-class), with no differences between sites (model $\left\{\phi_{\mathrm{a} 2 \mathrm{v}}, p_{\mathrm{g}^{*} \mathrm{t}}\right\}$; Table 2). Parameter estimates for this "age"-class (averaged over all models in the candidate model set to account for uncertainty in model selectionsee Methods) declined monotonically over time at both Calamity Cove (1994: $0.655 \pm 0.044$; 1995: $0.375 \pm 0.053 ; 1996: 0.194 \pm 0.071)$ and South Bay (1994: $0.651 \pm 0.043$; 1995: 0.383 $\pm 0.054 ; 1996: 0.195 \pm 0.070$ ). Adult survival
$2+$ years after marking was not different between the two sites (Calamity Cove: $0.844 \pm$ 0.098; South Bay: $0.825 \pm 0.090$; pooled: 0.829 $\pm 0.095)$. This model was over twice as well supported by the data than a model for which adult survival differed between sites (0.498/ $0.208=2.4$ ). In contrast, there was significant heterogeneity in recapture rate among years and sites, ranging from 0.26 to 0.53 . However, this was due entirely to the low recapture rate estimated for Calamity Cove in 1996, which had the lowest total number of netting hours $(32 \mathrm{hr}$ in 1994; $39 \mathrm{hr}$ in 1995; $21 \mathrm{hr}$ in 1996; $46 \mathrm{hr}$ in 1997) and the lowest total number of captures. In general, there was a $40-45 \%$ chance of recapturing an individual Rhinoceros Auklet conditional on it being alive and in the sampling area.

Cassin's Auklet. Because $>94 \%$ of all the captures of Cassin's Auklets on Triangle Island occurred at Calamity Cove and West Bay, we restricted our analyses to these two sites. From 1994-1996, a total of 1,866 individuals were marked and released at these two sites, of which 772 were recaptured at least once (Table 1). As with the data for Rhinoceros Auklets, the data satisfactorily fit the two "age"-class global model $(P>0.19)$, with no evidence of significant extra-binomial variation in the data $(\hat{c}=$ $1.023 \pm 0.034$ ).

The most parsimonious model (model $\left\{\phi_{\mathrm{a} 2 \mathrm{~g}^{*} / \mathrm{J}}\right.$ - $\left.p_{g^{*} t}\right\}$; Table 3) was a model where the adult survival rates varied with (1) time during the year between the year of marking and the next year (the first "age"-class), and (2) banding location. Similar to our results for Rhinoceros Auklets, survival of Cassin's Auklets the year

TABLE 2. Summary of model testing for Rhinoceros Auklet banded as adults on Triangle Island, British Columbia. Models sorted by increasing $\mathrm{QAIC}_{c}$ value. Models with $\mathrm{QAIC}_{c}$ weights $>0.001$ are listed, with the most parsimonious model at the top. Subscripts reflect different factors in the model $(\mathrm{t}=\mathrm{time}, .=$ constant, $\mathrm{g}$ = banding location). The "a2" subscript refers to fitting a 2 "age"-class model (see text). $n p=$ number of estimable parameters

\begin{tabular}{|c|c|c|c|c|c|}
\hline Model & $\mathrm{QAIC}_{c}$ & $\Delta \mathrm{QAIC}_{c}$ & $\begin{array}{l}\text { QAIC } c \\
\text { weight }\end{array}$ & $n p$ & Deviance \\
\hline$\left\{\phi_{\mathrm{a} 2 t \cdot} p_{\mathrm{g} *_{\mathrm{t}}}\right\}$ & $1,961.55$ & 0.00 & 0.50 & 10 & 8.78 \\
\hline$\left\{\phi_{\mathrm{a} 2 t \mathrm{~g}} p_{\mathrm{g} *_{\mathrm{t}}}\right\}$ & $1,963.30$ & 1.74 & 0.21 & 11 & 8.47 \\
\hline$\left\{\phi_{\mathrm{a} 2 \mathrm{t} /} p_{\mathrm{t}}\right\}$ & $1,964.24$ & 2.69 & 0.13 & 7 & 17.91 \\
\hline$\left\{\phi_{\mathrm{a} 2 t_{\mathrm{g}}} p_{\mathrm{t}}\right\}$ & $1,965.43$ & 3.88 & 0.07 & 8 & 17.04 \\
\hline$\left\{\phi_{\mathrm{a} 2 \mathrm{~g} * \mathrm{t} /} p_{\mathrm{g} * \mathrm{t}}\right\}$ & $1,966.14$ & 4.59 & 0.05 & 13 & 7.18 \\
\hline$\left\{\phi_{\mathrm{a} 2 \mathrm{~g}^{*} / \mathrm{g}} p_{\mathrm{g}^{*} \mathrm{t}}\right\}$ & $1,968.15$ & 6.60 & 0.02 & 14 & 7.14 \\
\hline$\left\{\phi_{\mathrm{a} 2 \mathrm{~g} * \mathrm{t}}, p_{\mathrm{t}}\right\}$ & $1,968.77$ & 7.22 & 0.01 & 10 & 16.28 \\
\hline$\left\{\phi_{\mathrm{a} 2 \mathrm{~g} * / \mathrm{g}} p_{\mathrm{t}}\right\}$ & $1,969.74$ & 8.20 & 0.01 & 11 & 15.18 \\
\hline
\end{tabular}


TABLE 3. Summary of model testing for Cassin's Auklet banded as adults on Triangle Island, British Columbia. Models sorted by increasing $\mathrm{QAIC}_{c}$ value. Models with $\mathrm{QAIC}_{c}$ weights $>0.001$ are listed, with the most parsimonious model at the top. Subscripts as in Table 2.

\begin{tabular}{|c|c|c|c|c|c|}
\hline Model & $\mathrm{QAIC}_{c}$ & $\Delta \mathrm{QAIC}_{c}$ & $\begin{array}{l}\mathrm{QAIC}_{c} \\
\text { weight }\end{array}$ & $n p$ & Deviance \\
\hline$\left\{\phi_{\mathrm{a} 2 \mathrm{~g}_{*}} p_{\mathrm{g} *_{\mathrm{t}}}\right\}$ & $3,586.97$ & 0.00 & 0.40 & 13 & 11.90 \\
\hline$\left\{\phi_{\mathrm{a} 2 \mathrm{~g}} \cdot p_{\mathrm{g}^{*} \mathrm{t}}\right\}$ & $3,588.57$ & 1.59 & 0.18 & 10 & 20.03 \\
\hline$\left\{\phi_{\mathrm{a} 2 \mathrm{a}^{*} \mathrm{~g}} p_{\mathrm{g} *_{\mathrm{t}}}\right\}$ & $3,588.99$ & 2.02 & 0.15 & 14 & 11.89 \\
\hline$\left\{\phi_{\mathrm{a} 2 \mathrm{~g}_{\mathrm{g}}} p_{\mathrm{g} *_{\mathrm{t}}}\right\}$ & $3,589.49$ & 2.51 & 0.11 & 11 & 18.86 \\
\hline 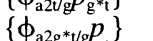 & $3,591.91$ & 4.94 & 0.03 & 9 & 25.73 \\
\hline$\left\{\phi_{a 2 g^{*}+t g} p_{\mathrm{g}}\right\}$ & $3,592.15$ & 5.17 & 0.03 & 10 & 23.84 \\
\hline$\left\{\phi_{\mathrm{a} 2 \mathrm{~g} * \mathrm{~g} g} p_{\mathrm{t}}\right\}$ & $3,592.22$ & 5.25 & 0.03 & 11 & 21.77 \\
\hline$\left\{\phi_{\mathrm{a} 2 \mathrm{~g} * \mathrm{v} \cdot} p_{\mathrm{t}}\right\}$ & $3,592.44$ & 5.47 & 0.03 & 10 & 24.15 \\
\hline$\left\{\phi_{\mathrm{a} 2 \mathrm{~g} * \mathrm{v} \cdot p} p\right\}$ & $3,592.52$ & 5.55 & 0.03 & 8 & 28.52 \\
\hline$\left\{\phi_{a 2 g^{*} v} p_{\mathrm{g}}\right\}$ & $3,593.61$ & 6.64 & 0.01 & 9 & 27.54 \\
\hline$\left\{\phi_{\mathrm{a} 2 \text { g g }} p\right\}$ & $3,597.89$ & 10.92 & 0.00 & 6 & 38.51 \\
\hline
\end{tabular}

after marking generally declined over time at both Calamity Cove (1994: $0.604 \pm 0.035$; 1995: $0.310 \pm 0.036 ; 1996: 0.295 \pm 0.069)$ and West Bay (1994: $0.576 \pm 0.030 ; 1995: 0.235 \pm$ 0.026 ; 1996 : $0.174 \pm 0.047$ ). Adult survival $2+$ years after marking was constant over time, and not different between the two sites (Calamity Cove: $0.669 \pm 0.051$; West Bay: $0.670 \pm 0.050$; pooled: $0.672 \pm 0.047$ ). This model was nearly three times as well supported by the data than a model for which adult survival differed between sites $(0.398 / 0.145=2.7)$, and also over twice as well-supported as a model for which time-dependent survival in the year after marking did not vary between banding locations $(0.398 /$ $0.179=2.2$ ). As with Rhinoceros Auklets, there was significant heterogeneity in recapture rate among years and sites, which ranged from 0.5 to 0.7 .

\section{INTERSPECIFIC COMPARISON}

To compare the two species, we fit model $\left\{\phi_{\mathrm{a} 2}\right.$ $\left.{ }_{\mathrm{g}}^{*} / \mathrm{g} p_{\mathrm{g}^{*}}\right\}$, treating each species as a separate group effect. We used the Rhinoceros Auklet and Cassin's Auklet data from Calamity Cove. Calamity Cove was the only site from which representative samples of both species were available, and for which data for both species was adequately fit by the starting model $(P>$ 0.51 ), with marginally significant extra-binomial variation $(\hat{c}=1.117 \pm 0.036)$.

A model where survival $2+$ years after marking was allowed to differ between species (i.e., between groups) was almost three times as well supported than a model where survival $2+$ years after marking was held constant between species (Table $4 ; 0.59 / 0.21=2.8$ ). Survival at Calamity Cove for Rhinoceros Auklets 2+ years after marking was estimated at $0.846 \pm 0.110$, whereas survival for Cassin's Auklets was $0.685 \pm$ 0.074 .

\section{DISCUSSION}

Our study revealed local adult survival values which were considerably lower (particularly for

TABLE 4. Summary of model testing comparing Rhinoceros Auklet and Cassin's Auklet banded as adults at Calamity Cove on Triangle Island, British Columbia. Models sorted by increasing QAIC $c$ value. Models with $\mathrm{QAIC}_{c}$ weights $>0.001$ are listed, with the most parsimonious model at the top. Subscripts as in Table 2 (except $\mathrm{g}=$ species).

\begin{tabular}{|c|c|c|c|c|c|}
\hline Model & $\mathrm{QAIC}_{c}$ & $\Delta \mathrm{QAIC}_{c}$ & $\begin{array}{l}\mathrm{QAIC}_{c} \\
\text { weight }\end{array}$ & $n p$ & Deviance \\
\hline$\left\{\phi_{\mathrm{a} 2 \mathrm{~g} * \mathrm{*g}} p_{\mathrm{g} *_{\mathrm{t}}}\right\}$ & $1,998.84$ & 0.00 & 0.59 & 11 & 8.79 \\
\hline$\left\{\phi_{\mathrm{a} 2 \mathrm{~g} * \mathrm{t} \cdot} p_{\mathrm{g} *_{\mathrm{t}}}\right\}$ & $2,000.86$ & 2.02 & 0.21 & 10 & 13.32 \\
\hline$\left\{\phi_{\mathrm{a} 2 \mathrm{~g} * t \cdot} p_{\mathrm{g} *_{\mathrm{t}}}\right\}$ & $2,001.91$ & 3.07 & 0.13 & 13 & 7.66 \\
\hline$\left\{\phi_{\mathrm{a} 2 \mathrm{~g} * \mathrm{t} / \mathrm{g}} p_{\mathrm{g} *_{\mathrm{t}}}\right\}$ & $2,003.52$ & 4.68 & 0.06 & 14 & 7.18 \\
\hline 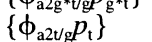 & $2,007.58$ & 8.75 & 0.01 & 8 & 25.37 \\
\hline$\left\{\phi_{\mathrm{a} 2 \mathrm{~g} * \mathrm{*} \mathrm{g}} p_{\mathrm{t}}\right\}$ & $2,009.58$ & 10.74 & 0.00 & 11 & 20.78 \\
\hline$\left\{\phi_{\mathrm{a} 2 \mathrm{~g} g} p_{\mathrm{g}}\right\}$ & $2,009.75$ & 10.91 & 0.00 & 7 & 30.04 \\
\hline
\end{tabular}


Cassin's Auklets) than previous estimates for many other seabird populations. Most auk species for which estimates have been made have survival rates in excess of $85 \%$ (Gaston and Jones 1998). The low adult survival estimate for Cassin's Auklet (0.67) is consistent with a possible decline in population size at the world's largest colony on Triangle Island based upon independent burrow monitoring, evidence of poor reproductive performance in recent years concurrent with our survival study, and long term declines in the California Current zooplankton and seabird populations. The breeding population was estimated in 1989 using labor-intensive transect methods but has not been resurveyed (Rodway 1991). However, independent evidence for a recent population decline is available from inspections of permanent monitoring plots in the colony. The total number of active burrows in 11 permanent monitoring plots declined from 2,289 in 1989 to 2,055 in $1994\left(2 \%\right.$ year $\left.^{-1}\right)$, immediately prior to our survival study (M. Lemon, unpubl. data), a significant decrease based on within-plot differences $\left(t_{10}=2.4, P=0.04\right)$. A $65 \%$ decline of the Cassin's Auklet population on the Farallon Islands from 1972-1997 has been linked with an adult annual survival rate $( \pm \mathrm{SE}$ ) of approximately $70 \pm 2 \%$ for birds breeding in artificial nestboxes (Nur et al. 1998). The decline in the Farallon population of Cassin's Auklet has been linked (Ainley et al. 1996) to a significant long term decline in zooplankton production in the California Current system (Roemmich and McGowan 1995) which has affected the abundance of other seabird populations (Viet et al. 1996). In British Columbia, earlier zooplankton availability (Mackas et al. 1998) and low levels of nutrients in surface waters (Whitney et al. 1998) in the 1990s are likely related to recent poor reproductive performance for Cassin's Auklet on Triangle Island (pers. observ.). The extent of recent large scale oceanographic changes and their effects on auklet populations thus deserves further study. Note that at more northern locations there is no evidence of population change or recent reproductive failure for Cassin's Auklet populations. In northern British Columbia, Gaston (1992) reported local adult survival for year $2+$ as 0.88 (95\% confidence interval 0.73-0.95) for breeding Cassin's Auklet from a small but stable colony $(1,700$ pairs) at Reef Island. In addition, Cassin's Auklet reproductive performance on Frederick Is- land in northern British Columbia has been consistently better than at Triangle Island in recent years (1994-1998; A. Harfenist, pers. comm.).

Our survival estimate for the Rhinoceros Auklet is the first for the species. The value appears low compared to all available estimates for Atlantic Puffins (Fratercula arctica; Hudson 1985, Harris et al. 1997) which have a similar body mass and feeding ecology to the Rhinoceros Auklet. There is, however, no independent evidence for a population decline on Triangle Island. Surveys of five permanent monitoring plots, which were intact before our survival study began, could not detect a significant trend in the number of active burrows in 1984 (494), 1989 (589), and 1994 (449; M. Lemon, unpubl. data). Furthermore, Rodway et al. (1992) suggested that the extent of the colony expanded on Triangle Island between 1984 and 1989.

Additional factors which could contribute to the observed survival values include possible emigration, colony attendance patterns, and age structure effects, but a thorough evaluation of these variables must await a longer time series.

For both species there was a tendency for survival rate the year following marking to decline over the years of our study. The decline might reflect a true decrease in survival the year following marking. This might be reasonable if human activity behind the netting areas has increased systematically since 1994 , but activity levels have been similar between 1996 and 1997. We therefore think this explanation is unlikely, and argue instead that the decline reflects an artifact of the sampling design in our study. We suggest that the decline may reflect an interannual decline in the proportion of transients in our sample of banded birds. Assume that the population has a constant ratio of residents to transients and that both groups are captured in proportion to their overall frequency in the population. In the first year of captures, the ratio of resident to transients will be maximal. With each additional year, as the proportion of banded birds in the sample increases, the proportion of residents to transients is likely to decline at some rate and hence the apparent survival will also decline, as we observed (Appendix).

In conclusion, our intensive study provides first estimates of local survival for Cassin's Auklet from their largest colony, and the first survival estimate for the Rhinoceros Auklet. For both species, the survival estimates were lower 
than most estimates for auk species. For Cassin's Auklet, the low survival rates are consistent with a current population decline as has been observed on the Farallon Islands (Nur et al. 1998), but additional data are required to validate the $\rightarrow$ suspected trend on Triangle Island. The possibility of a population decline is compelling particularly in light of the recent large-scale oceanographic changes in the northeast Pacific and its documented effects on marine trophic webs (Roemmich and McGowan 1995, Mackas et al. 1998). As the mark-recapture program contin ues, the local survival estimates will become more robust and comparisons of interannual variability will be facilitated. We plan to examine the relationship between variation in prey availability and breeding propensity to investigate the effects of breeding avoidance on the magnitude of estimates of survival. By coupling the survival estimates with regularly obtained indexes of population size (Rodway et al. 1992, Bertram et al. 1999), with a program which examines variation in reproductive success, we will be able to quantify population trends and their causes and thus make robust predictions about the future status of the populations.

\section{ACKNOWLEDGMENTS}

The British Columbia Ministry of Environment Lands and Parks provided the permit to work on the Anne Vallée Ecological Reserve, Triangle Island. We thank the many volunteers and technicians for assistance with auklet capture-recapture. Connie Smith helped collate and organize the dataset. We thank the Canadian Wildlife Service (CWS) and particularly Gary Kaiser for providing funding in 1994 and continued logistic support. Moira Lemon (CWS) kindly provided unpublished data on monitoring plot surveys. Financial support was provided by Natural Sciences and Engineering Research Council (NSERC) of Canada grants to Fred Cooke and Tony Williams and from the CWS/ NSERC Research Chair of Wildlife Ecology at Simon Fraser University. Construction of the research station was made possible by a generous grant from the Vancouver Foundation. We are indebted to the Canadian Coast Guard for essential ship and helicopter support.

\section{LITERATURE CITED}

Ainley, D. G., L. B. Spear, AND S. G. Allen. 1996 Variation in the diet of Cassin's Auklet reveals spatial, seasonal, and decadal occurrence patterns of euphausiids off California, USA. Mar. Ecol. Prog. Ser. 137:1-10.

Bertram, D. F., L. Cowen, and A. Burger. 1999. Use of radar for monitoring colonial burrow-nesting seabirds. J. Field Ornithol. 70:145-157.

Buckland, S. T., K. P. Burnham, and N. H. Augustin.
1997. Model selection: an integral part of inference. Biometrics 53:603-618.

Burnham, K. P., AND D. R. ANDERSON. 1998. Model selection and inference-a practical informationtheoretic approach. Spring-Verlag, New York.

Emslie, S. D., R. P. Henderson, and D. G. Ainley. 1990. Annual variation of primary molt with age and sex in Cassin's Auklet. Auk 107:689-695.

Gaston, A. J. 1992. Annual survival of breeding Cassin's Auklets in the Queen Charlotte Islands, British Columbia. Condor 94:1019-1021.

GASTON, A. J., AND I. L. JonEs. 1998. Bird families of the world: the Auks (Alcidae). Oxford Univ. Press, Oxford.

Harris, M. P, S. N. Freeman, S. Wanless, B. J. T. MORGAN, AND C. V. WERnhAM. 1997. Factors influencing the survival of Puffins Fratercula arctica at a North Sea colony over a 20-year period. J. Avian Biol. 28:287-295.

Hudson, P. J. 1985. Population parameters for the Atlantic Alcidae, p. 233-261. In D. N. Nettleship and T. R. Birkhead [EDS.], The Atlantic Alcidae. Academic Press, Orlando, FL.

Lebreton, J.-D., K. P. Burnham, J. Clobert, and D. R. ANDERSON. 1992. Modelling survival and testing biological hypotheses using marked animals: a unified approach with case studies. Ecol. Monogr. 62:67-118.

Mackas, D. L., R. Goldblatt, and A. G. Lewis. 1998. Interdecadal variation in developmental timing of Neocalanus plumchrus populations at Ocean Station $\mathrm{P}$ in the subarctic North Pacific. Can. J. Fish. Aquat. Sci. 55:878-1893.

$\rightarrow$ Manuwal, D. A. 1978. Criteria for aging Cassin's Auklets. Bird Banding 49:157-161.

Nur, N., W. J. Sydeman, M. Hester, And P. Pyle. 1998. Survival in Cassin's Auklets on Southeast Farallon Island: temporal patterns, population viability, and the cost of double brooding. Pacific Seabirds 25:38. (Abstract)

RoDWAY, M. S. 1991. Status and conservation of breeding seabirds in British Columbia. Int. Council Bird Preserv. Tech. Publ. No. 11:43-102.

Rodway, M. S., M. J. F. Lemon, AND K. R. Summers. 1992. Seabird breeding populations in the Scott Islands on the west coast of Vancouver Island, 1982-89, p. 52-59. In K. Vermeer, R. W. Butler, and K. H. Morgan [EDS.], The ecology, status, and conservation of marine and shoreline birds on the west coast of Vancouver Island. Occas. Paper No. 75. Can. Wild. Serv., Ottawa.

RoEmmich, D., AND J. McGowan. 1995. Climate warming and the decline of zooplankton in the California Current. Science 267:1324-1326.

Veit, R. R., P. Pyle, and J. A. McGowan. 1996. Ocean warming and long-term change in pelagic bird abundance within the California Current system. Mar. Ecol. Prog. Ser. 139:11-18.

Vermeer, K., R. A. Vermeer, K. R. Summers, ANd R. D. BILlings. 1979. Numbers and habitat selection of Cassin's Auklets breeding on Triangle Island, British Columbia. Auk 96:143-151.

Wallace, G. E., B. Collier, and W. J. Sydeman. 1992. Interspecific nest-site competition among 
cavity-nesting alcids on Southeast Farallon Island, California. Colonial Waterbirds 15:241-244.

White, G. C., and K. P. Burnham. 1999. Program MARK - survival estimation from population of marked animals. Bird Study 46, in press.

Whitney, F. A., C. S. Wong, And P. W. Boyd. 1998. Interannual variability in nitrate supply to surface waters of the Northeast Pacific Ocean. Mar. Ecol. Prog. Ser. 170:15-23.

\section{APPENDIX}

To demonstrate the effects of (1) constant total sample size and (2) constant proportions of resident and transient individuals on apparent survival over the first interval after marking, we consider a population consisting of 1,000 individuals, of which there are $80 \%$ resident and $20 \%$ transient individuals in all years. We assume that in each year, $50 \%$ of all individuals in the population are captured. True annual adult survival is set at $\phi=0.8$. If $p=1.0$, then we can show algebraically that apparent survival over the first interval, estimated as proportion of newly banded birds released in year (i) seen again in year $(i+1)$ decreases from 0.64 in the first year $(\{400 \cdot 0.8\} / 500$, where $500=400$ residents +100 transients marked and released), to 0.51 in the third year. The proportion recaptured increases from $0 \%$ in year 1 to $45 \%$ in year 3 , approximately equal to that observed in our study for Rhinoceros Auklets. Ultimately, the first interval survival rate asymptotes, coincident with the point at which the proportion of recaptures in the banding sample no longer increases (Figure below).

If the sampling fraction is increased from $50 \%$ to $70 \%$, then first interval survival declines even more dramatically, from 0.64 in the first year, to 0.36 in the third year. However, under this scenario, the percentcage of recaptures in the sample rises to $64 \%$, significantly more than observed in our study for either species. Our purpose here is only to suggest the potential role this sort of sampling regime may have on the apparent first interval survival rate. If the sampling fraction is high, and if there are fairly constant numbers of individuals in the population (consisting both of residents and transients), then first-year estimates will decline over time. The actual rate and magnitude of the decline are determined by (1) the sample fraction and (2) the population frequencies of residents and transients. The larger the sample fraction, or the greater the proportion of transients in the population, the faster (and larger) the decline. In our Rhinoceros Auklet data, for example, the proportion of recaptures in the annual sample increased from $<1 \%$ in 1994 (recaptures of birds banded in previous studies) to $39 \%$ in $1995,55 \%$ in 1996 , and $43 \%$ in 1997.

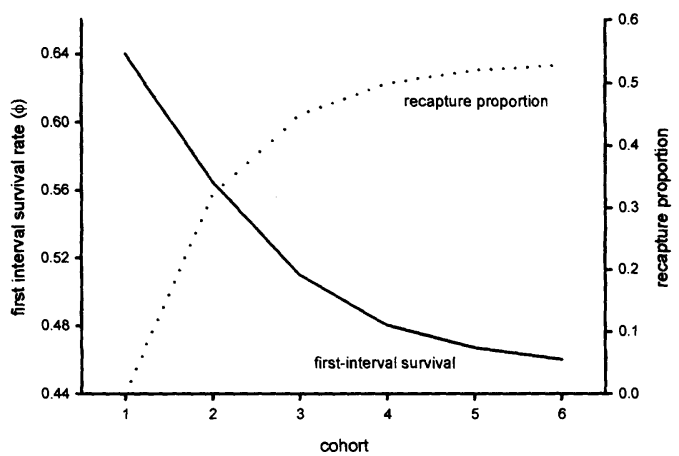

